\title{
An Archaeological Assessment of the Gentry-McLean Leases, Live Oak County, Texas
}

Michael Woerner

Follow this and additional works at: https://scholarworks.sfasu.edu/ita

Part of the American Material Culture Commons, Archaeological Anthropology Commons, Environmental Studies Commons, Other American Studies Commons, Other Arts and Humanities Commons, Other History of Art, Architecture, and Archaeology Commons, and the United States History Commons

Tell us how this article helped you.

This Article is brought to you for free and open access by the Center for Regional Heritage Research at SFA ScholarWorks. It has been accepted for inclusion in Index of Texas Archaeology: Open Access Gray Literature from the Lone Star State by an authorized editor of SFA ScholarWorks. For more information, please contact cdsscholarworks@sfasu.edu. 


\section{An Archaeological Assessment of the Gentry-McLean Leases, Live Oak County, Texas}

\section{Creative Commons License}

\section{(c) (1) (8)}

This work is licensed under a Creative Commons Attribution-NonCommercial 4.0 International License 


\section{AN ARCHAEOLOGICAL ASSESSMENT OF THE GENTRY-MCLEAN LEASES, LIVE OAK COUNTY, TEXAS}

Michael Woerner

Center for Archaeological Research The University of Texas at San Antonio Archaeological Survey Report, No. 96 
AN ARCHAEOLOGICAL ASSESSMENT OF THE GENTRY-MCLEAN LEASES,

LIVE OAK COUNTY, TEXAS

Michael Woerner

Center for Archaeological Research The University of Texas at San Antonio Archaeological Survey Report, No. 96 
List of Figures. . . . . . . . . . . . . . . . . i

Introduction ...................... . . 1

Previous Archaeological Research . . . . . . . . . . . . . . 1

The Survey . . . . . . . . . . . . . . . . . . . . . 1

Summary and Recommendations. . . . . . . . . . . . . . . 4

References cited ................... . . 6

\section{LIST OF FIGURES}

Figure

1. Locations of Proposed Drainage Trench I and II on the McLean and Gentry Tracts and Archaeological Sites in the Vicinity. . . . . . 2

2. Artifacts Collected from the Surface of Site 41 LK 109 ...... 5 


\section{INTRODUCTION}

On June 26 and 27, 1980, archaeologists from the Center for Archaeological Research (CAR), The University of Texas at San Antonio (UTSA), conducted cultural resource surveys on the McLean and Gentry leases north of Oakville, Live 0ak County, Texas. The survey was done under contract between the CAR and the Exxon Minerals Company, U.S.A. (Work Order No. 00212, dated June 6, 1980). The fieldwork was carried out by Thomas C. Kelly and Michael Woerner, CAR archaeologists, under the supervision of Dr. Thomas R. Hester, Director, and Jack D. Eaton, Acting Director.

\section{PREVIOUS ARCHAEOLOGICAL RESEARCH}

A number of archaeological projects involving survey and testing have been conducted in Live Oak County over the past several years. The most sustained research has been for the Choke Canyon projects in the general vicinity of Three Rivers (Ma1louf 1975; Lynn et al. 1977), with continuing fieldwork by the Center for Archaeological Research. The State Department of Highways and Transportation conducted excavations in 1979 at an Archaic burial ground (41 LK 28) situated near the junction of highways 37 and 281 north of Three Rivers (Chuck Johnson, personal communication). Area surveys conducted by the Center in northern Live Oak County for the Conquista Project (Smith 1978; McGraw 1979) have located several aboriginal sites.

Prior to the current survey, other surveys and site testing have been conducted on the Felder-McLean leases for Exxon Minerals Company, U.S.A., by the Center (Kelly and Hester 1977; Creel et al. 1978). The survey by Kelly in 1977 located 10 archaeological sites on the McLean tract (41 LK 103-112). Site 41 LK 106, a Middle to Late Archaic and Late Prehistoric occupation site located to the east of the current study area, was excavated in 1978 by Creel. Three other sites (41 LK 109,110, and 112) found by Kelly during the 1977 survey are located on a ridge just to the north of the proposed drainage trench near sulphur Creek. These will be considered in the following report.

\section{THE SURVEY}

The areas surveyed lie on the north side of Sulphur Creek and total more than 51 acres (Fig. 1). The purpose of the survey was to make a cultural resource assessment of the two areas (designated Areas $A$ and $B$ ) where drainage trenches (designated Trench I and II) are planned.

\section{Area $A$}

This area lies within the Gentry tract north of county road BR 180 . The area has recently been cleared, and vegetation consists of short grasses and occasional oak and mesquite. The soil in the area is medium to dark brown sandy loam.

Drainage Trench I, some 2,200 feet long with a right-of-way of 250 feet either 
This page has been

redacted because it

contains restricted

information. 
side of the center line, is planned for this area. The trench witi begin on the north side of county road BR 180 and extend northwest (Fig. 1).

The survey of Trench I right-of-way was conducted by the two-man field team walking about 25 meters apart for the length of the proposed trench. Each man "dog-legged" to cover an area 50 meters wide. The process was repeated until the entire area had been covered. Where terrain and vegetation permitted, areas outside of the right-of-way. were examined.

No cultural resources were found within the survey right-of-way. Although land snail shells, notably Rabdotus sp. (often associated with archaeological sites), were seen scattered on the surface in the area, there were no concentrations which might indicate past cultural activity.

However, outside and to the west of the proposed trench right-of-way, a smal1 lithic scatter was noted and recorded. The scatter was located about 200 meters north of road BR 180 and 30 meters west of the Exxon survey stake marked $12+00$ CL ELE 2098 (Fig. 1). Here, 1ithic debris was scattered over an area of about 20 meters. Because this represented the only cultural material observed in the Area A survey, a total surface collection was made. The collection includes a biface fragment; one each of secondary, interior, and thinning flakes; and several chunks of chert, two of which are fire cracked. The lithic scatter does not represent a significant cultural resource, and no further work is needed.

\section{Area B}

This area lies within the McLean tract and is bisected by Sulphur Creek. The area was not cleared of vegetation at the time of the survey, and the cover consists of dense chaparral--mainly small oak, mesquite, and low thorny brush typical of south Texas. Ground visibility was very poor. The soil in this area is a light tan to medium brown sandy loam.

Trench II is planned for this area and will be roughly 7,000 feet long, with a 250 foot right-of-way each side of center line. The trench will follow an irregular land contour just to the north of Sulphur Creek (Fig. 1). Because of the dense vegetation, the exact routing of the planned trench was not clearly apparent. Therefore the survey of this area was conducted only as thoroughly as vegetation allowed.

Four previously located archaeological sites (41 LK 109,110,111, and 112) are in the vicinity of proposed Trench II. These sites were found and described by Thomas C. Kelly during a survey for the Exxon Minerals Company in 1977 (Kelly and Hester 1977). Sites 41 LK 109 and 41 LK 110 were relocated during the current survey in order to note their locations with respect to the proposed trench route. Due to the dense undergrowth, sites 41 LK 111 and 41 LK 112 were not relocated.

Site 41 LK 109 lies just below the top of a ridge roughly 500 meters northnorthwest of Sulphur Creek. Chert knapping debris, which basically defines the site size, extends over an area of approximately 20 meters. During the original survey of the site (Kelly and Hester 1977), three unidentified dart point frag- 
ments and a small end scraper were found. The site has experienced some leaching in the past three years, and when visited during the current survey, additional artifacts were found. These include a Guadalupe gouge tool (Fig. 2,a), a biface fragment (Fig. 2,b), and a triangular dart point (Fig. 2,C).

Site 41 LK 110 is exposed in a sma11, shallow gully located about 100 meters south-southwest of 41 LK 109 and along the crest of the same ridge. The gully is oriented north south, with drainage to the south. It is on one of the highest points in the area overlooking Sulphur Creek. Lithic material is exposed for approximately 50 meters along the gully and averages 10 meters in width. Diagnostic artifacts collected during the original survey and testing (Kelly and Hester 1977) include three Tortugas points, and one each of probable Pedernales and Desmuke points. No additional artifacts were found during the current survey. The site evidently dates to the Archaic period. Kelly and Hester (ibid.) have recommended that, should the site be threatened by future developments, further investigations which include testing should be carried out.

As best as it can be determined, site 41 LK 110 may 1 ie at or near the north edge of the proposed trench right-of-way. The other sites mentioned above are at a greater distance and possibly would not be affected by the trenching.

\section{SUMMARY AND RECOMMENDATIONS}

The archaeological survey of the Gentry tract (Area A), where Trench I is to be located, did not reveal any significant cultural resources which would be affected by planned developments. A small lithic scatter was noted and collected well outside of the estimated trench right-of-way, but this was determined to be an insignificant resource and would not be disturbed by trench operations. No further work would be needed in the area of Trench I.

The survey on the McLean tract (Area B), where Trench II is planned, revealed no additional archaeological sites beyond those recorded by Kelly during a previous survey, which concentrated on the area to the east of the current survey area (Kelly and Hester 1977). Archaeological sites 41 LK 109, 110, and 112 are in the vicinity of the estimated routing of Trench II. The vegetation in this area is dense, and the trench route is currently unmarked; therefore, the survey could not determine with any degree of confidence that there are no additional cultural resources in the study zone, or that the three known sites located nearby would not be threatened by developments.

Due to the dense vegetation, we would recommend that, once the right-of-way for Trench II has been cleared, an archaeologist should re-examine the route for any additional cultural resources and for the proximity of sites 41 LK 109, 110, and 112 to the right-of-way. If the sites lie outside of the right-of-way, or if the trench routing can be altered to avoid them, the sites could be protected and no further work would be necessary. However, if any of the sites are to be threatened by trenching activities, they should be tested by a qualified archaeologist for cultural resource evaluation. 


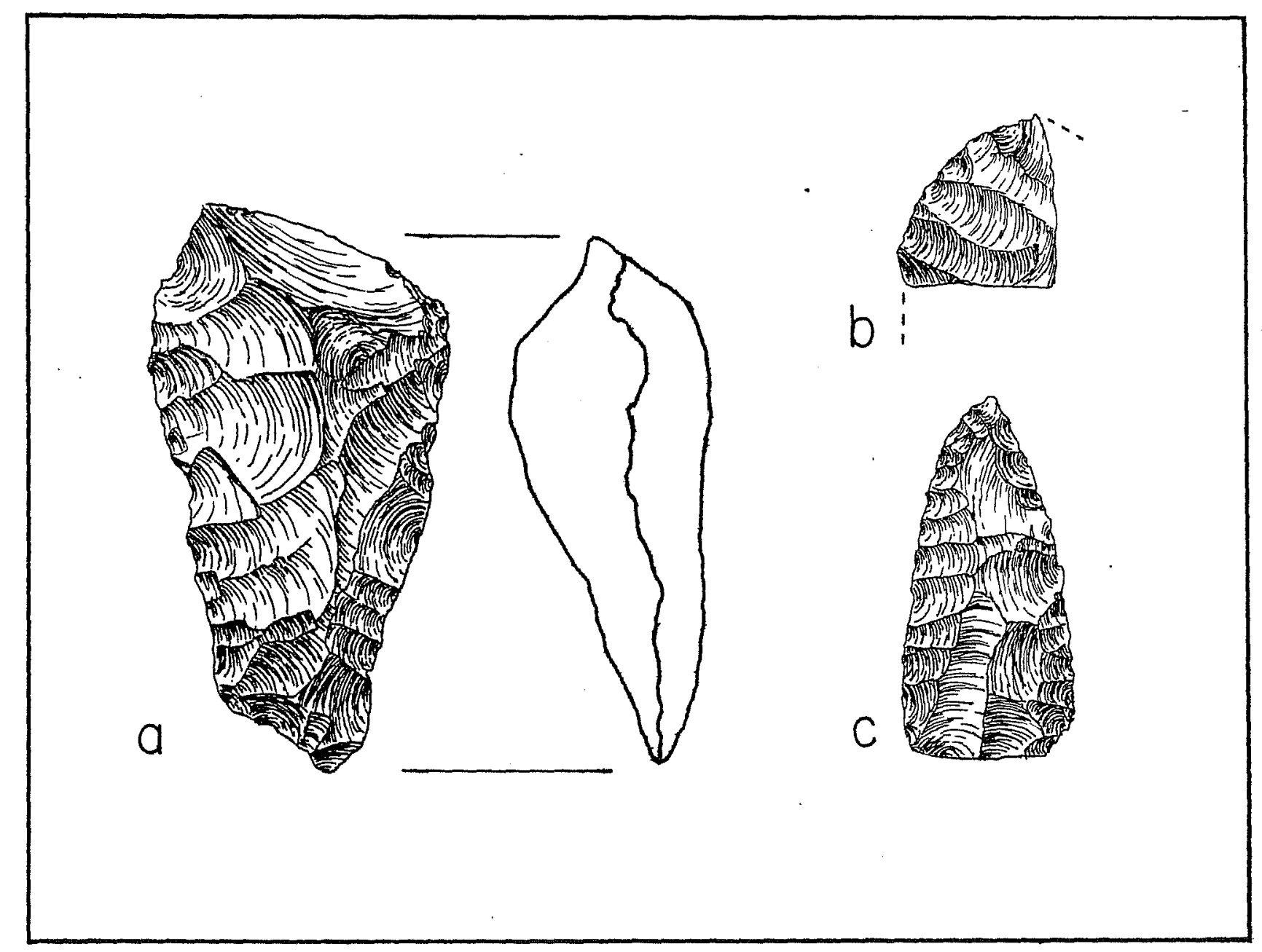

Figure 2. Artifacts collected from the Surface of Site 41 LK 109. a, Guadalupe gouge; b, biface fragment; $c$, triangular dart point. Artifacts are actual size. 


\section{REFERENCES CITED}

Creel, D., A. McGraw, F. Valdez, Jr., and T. Kelly

1978 Excavations at 41 LK 106, A Prehistoric Occupation Site in Live Oak County, Texas. Center for Archaeological Research, The University of Texas at San Antonio, Archaeological Survey Report 62.

KelTy, T.

1977 Archaeological Assessment of Cultural Resources on the FelderMcLean Leases, Live Oak County, Texas. Report submitted to Exxon Minerals Company, USA, by the Center for Archaeological Research, The University of Texas at San Antonio.

Lynn, W., D. Fox, and N. O'Ma1ley

1977 Cultural Resource Survey of Choke Canyon Reservoir, Live Oak and McMullen Counties, Texas. Texas Historical Commission, Archaeological Survey Report 20.

McGraw, A.

1979 A Preliminary Archaeological Survey for the Conquista Project in Gonzales, Atascosa and Live Oak Counties, Texas. Center for Archaeological Research. The University of Texas at San Antonio, Archaeological Survey Report 76.

Mal1ouf, M.

1975 Three Rivers Flood Protection Project, Live Oak County, Texas: An Archaeological and Historical Survey of Areas Proposed for Modification. Report to the Fort Worth District Corps of Engineers by the Texas Archeological Survey, The University of Texas at Austin.

Smith, H.

1978 Archaeological Survey and Assessment of Properties for the Conquista Project in Live Oak and Karnes Counties, Texas. Center for Archaeological Research, The University of Texas at San Antonio, Archaeological Survey Report 64. 